\title{
Oral Pyogenic Granuloma after Tongue Piercing Use: Case Report
}

\section{Patussi C, Sassi LM, Da Silva WP, Zavarez LB and Schussel JL*}

Department of Oral and Maxillofacial Surgery, Erasto Gaertner Hospital, Curitiba, Brazil

\begin{abstract}
The wearing of piercings on tongue, lips, cheeks and frenuluns have become more popular and may cause complications in oral tissues, such as inflammatory reaction. Oral pyogenic granuloma can occur in lips, tongue, buccal mucosa and most often on the gingiva, which corresponds to $75 \%$ of all cases. The present study report a case of pyogenic granuloma in tongue due to the use of oral piercing. It is important that professionals and public are aware of the possible complications related to the use of this intra-oral ornament.
\end{abstract}

Keywords: Pyogenic granuloma; Piercing; Tongue

\section{Introduction}

The wearing of piercings on tongue, lips, cheeks and frenuluns have become more popular and may cause complications in oral tissues, such as infection, inflammation, dental fractures, trauma to the mucosa and periodontal tissue, difficulty in speaking, swallowing and chewing [1].

The pyogenic granuloma is a distinctive clinical entity, originating from a response of the tissues to various stimuli like low-grade local irritation, traumatic injury, sex hormones, bone marrow transplants and reactions to grafts [2]. Oral pyogenic granuloma can occur in lips, tongue, buccal mucosa and most often on the gingiva, which corresponds to $75 \%$ of all cases [3], with female predilection. Differential diagnosis include other reddish nodular lesion on oral mucosa [4].

The objective of this study is to present a case report of a pyogenic granuloma in tongue due to the presence of oral piercing, guiding the professionals and public about the possible complications related to the use of this intra-oral ornament.

\section{Case Report}

A 23 years-old leucoderm woman was referred to Service of Oral and Maxillofacial Surgery of Erasto Gaertner Hospital (EGH), (Curitiba-PR, Brazil) complaining of a tumor on her tongue. The patient referred as medical condition hypothyroidism, mitral valve prolapse, hypertension, depression and sinusitis.

Intra oral exam presented a pedunculated lesion on the dorsum of tongue, at midline region. The nodule was reddish, bleeding to the touch, painless with rough surface, measuring approximately $15 \mathrm{~mm}$ in its largest diameter (Figure 1). Patient reported use of a tongue piercing in the same area for 3 years that was removed two

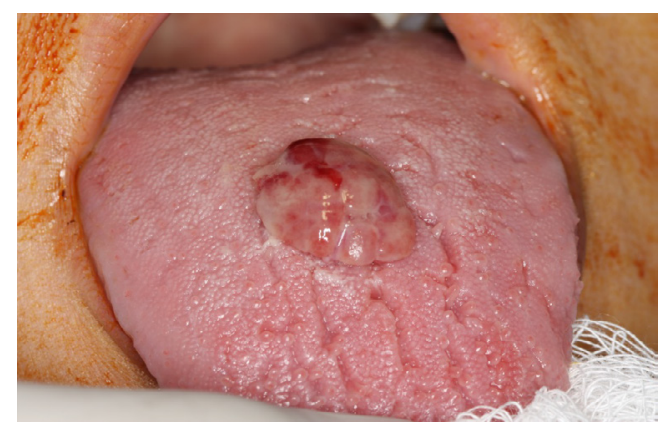

Figure 1: Clinical aspect of tongue lesion at first exam. years before. The lesion was noted about 5 months before the first appointment.

The lesion was fully resected (Figure 2). Histopathological features showed an ulcerated lesion with endothelial cell proliferation and edematous stroma. Inflammatory cell infiltrate with scattered eosinophils was observed as well regenerating epithelium at the ulcer edge confirming the diagnostic of pyogenic granuloma (Figure 3 ).

The patient had a good outcome and showed no signs of recurrence after 12 months of follow-up (Figure 4).

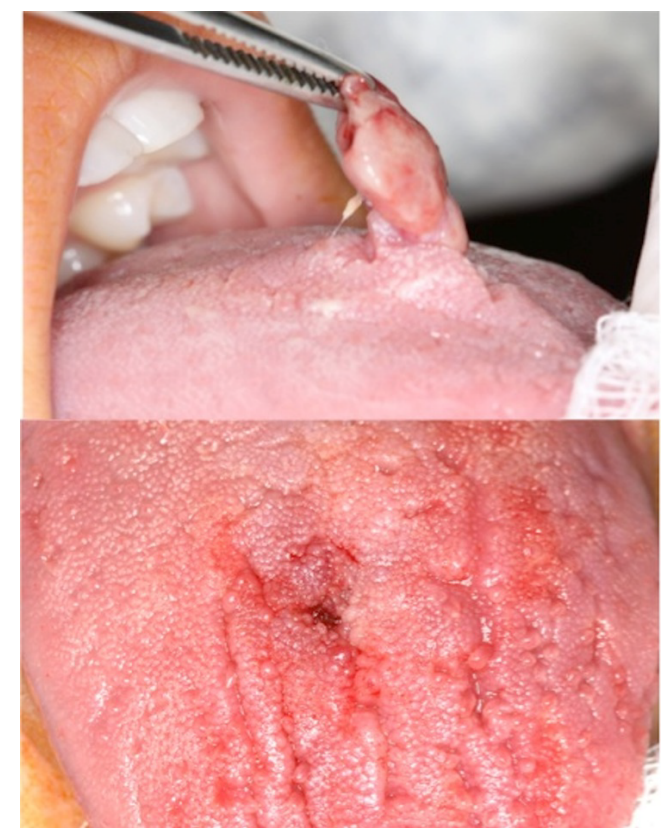

Figure 2: Total lesion excision, showing pedunculated feature.

*Corresponding author: Juliana L Schussel, Rua Dr. Ovande do Amaral, 201, 81520060, Brazil, Tel: 55413361 5285; E-mail: juliana.schussel24@gmail.com

Received February 20, 2014; Accepted March 27, 2014; Published March 29 2014

Citation: Patussi C, Sassi LM, Da Silva WP, Zavarez LB, Schussel JL (2014) Oral Pyogenic Granuloma after Tongue Piercing Use: Case Report. Dentistry 4: 229 doi:10.4172/2161-1122.1000229

Copyright: $\odot 2014$ Patussi C, et al. This is an open-access article distributed under the terms of the Creative Commons Attribution License, which permits unrestricted use, distribution, and reproduction in any medium, provided the original author and source are credited. 


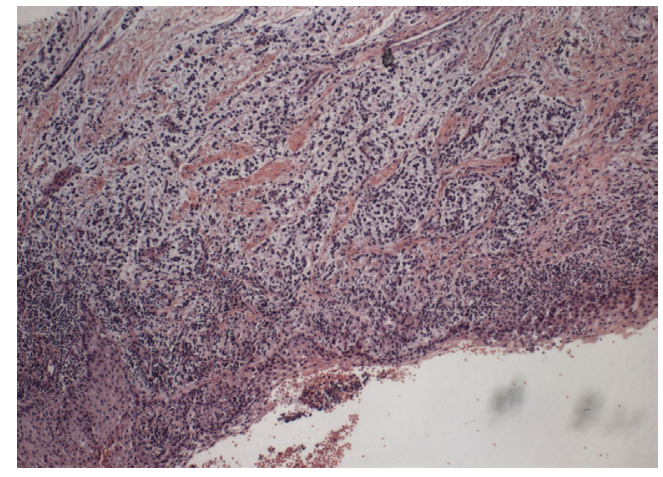

Figure 3: Histological image, showing ulcerated area and endothelial cell proliferation.

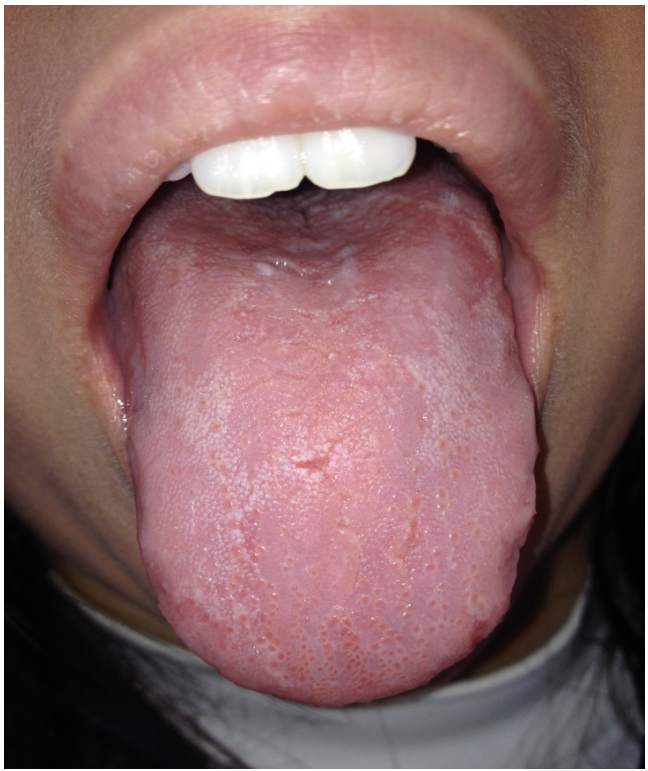

Figure 4: After 12 months follow-up, patient had no signs of recidive.

\section{Discussion}

Oral pyogenic granuloma (OPG) is a relatively common inflammatory hyperplasia, that unlike its name suggest, resembles an angiomatous lesion. The oral mucosa is the most common site of appearing, but can occur in the tongue, lips, palatine and periodontal region $[2,5]$.

In our case, the lesion presented in the same area where patient reported a tongue piercing. Although the patient had removed the ornament two years before the appointment, the perforation of the tongue for the piercing installation left a scar area with irregular aspects that is more likely to accumulate biofilm and consequently more prone to inflammation.

The pathogenesis of this reactive proliferative process can be associated with local trauma, being the gingival irritation and inflammation due to poor oral hygiene the precipitating factor. Local irritation, biofilm, dental calculus, gingival inflammation, neonatal teeth, protruding filling margins, hormonal changes (pregnancy and menarche) are other factors that may cause this reaction [2,68]. Differential diagnosis include peripheral giant cell granuloma, peripheral ossifying fibroma, metastatic cancer, hemangioma, conventional granulation tissue, hyperplastic gingival inflammation, angiosarcoma and Non-Hodgkin's lymphoma [4].

The use of oral piercings can cause mechanical trauma to oral tissues, tooth fracture, speech impediment, pain, aspiration, lip inflammation, localized tissue overgrowth, pathologic conditions such as bacterial infections, edema, allergies, lingual laceration, black tongue, galvanism, scar tissue formation, increased salivary flow, interference with radiographic images, nerve damage and paresthesia [9-12]. The case reported, was clearly observed the correlation between the oral piercing with the appearance of the OPG. There is a lack of studies reporting this type of lesion caused by long-term use of tongue piercing [13].

The body piercing happens for centuries and seems that will not have an early end. Thus, the surgeon's responsibility is to clarify the patient of all possible consequences of this, making clear that the habit can be a risk for oral, dental and general health.

\section{References}

1. Bozelli JV, Matsui RH, Faltin Jr K, Ortolani CF, Chelloti A (2004) Oral and perioral piercing: the fashion that marks. Rev Inst Ciênc Saúde 22: 331-336.

2. Krishnapillai R, Punnoose K, Angadi PV, Koneru A (2012) Oral pyogenic granuloma--a review of 215 cases in a South Indian Teaching Hospital Karnataka, over a period of 20 years. Oral Maxillofac Surg 16: 305-319.

3. Regu P, Sharma A, Manoharan GVMG (2013) Pyogenic Granuloma of the Tongue - a rare clinical finding. Int J Dent Case Reports 3: 57-61.

4. Sharma A, Vikramb A, Bhadanid PP, Singhc G, Kumare A (2012) Aggressive invasive oral pyogenic granuloma: a case report. Indian Journal of Dentistry 3: 81-85.

5. Angelopoulos AP (1971) Pyogenic granuloma of the oral cavity: statistical analysis of its clinical features. J Oral Surg 29: 840-847.

6. Terezhalmy GT, Riley CK, Moore WS (2000) Pyogenic granuloma (pregnancy tumor). Quintessence Int 31: 440-441.

7. Aguilo L, Bagan JV (2002) Pyogenic granuloma subsequent to apical fenestration of a primary tooth. J Am Dent Assoc 133: 599-602.

8. Ramirez K, Bruce G, Carpenter W (2002) Pyogenic granuloma: case report in a 9-year-old girl. Gen Dent 50: 280-281.

9. Chambrone L, Chambrone LA (2003) Gingival recessions caused by lip piercing: case report. J Can Dent Assoc 69: 505-508.

10. Chimenos-Kustner E, Batlle-Trave I, Velasquez-Rengijo S, Garcia-Carabano T, Vinals-Iglesias, et al. (2003) Appearance and culture: oral pathology associated with certain "fashions" (tattoos, piercings, etc.). Med Oral 8: 197-206.

11. Botchway C, Kuc I (1998) Tongue piercing and associated tooth fracture. J Can Dent Assoc 64: 803-805.

12. Maheu-Robert LF, Andrian E, Grenier D (2007) Overview of complications secondary to tongue and lip piercings. J Can Dent Assoc 73: 327-331.

13. Ziebolz D, Hildebrand A, Proff P, Rinke S, Hornecker E, et al. (2012) Long-term effects of tongue piercing--a case control study. Clin Oral Investig 16: 231-237. 